\title{
Metabolic Fate of Timepidium Bromide (SA-504)
}

\author{
- Unstable Metabolites in the Rats - \\ Juko SUgIHARA and Naomasa TAGA* \\ Drug Metabolism Department and *Organic Chemistry Department, \\ Biological and Chemical Research Laboratories, \\ Tanabe Seiyaku Co., Ltd., \\ 2-2-50, Kawagishi, Toda-shi, Saitama 335 \\ Received December 4, 1976
}

\begin{abstract}
The colored substances excreted in bile or urine have been investigated after administration of a high dose of SA-504 to rats.

$A$ reddish-violet colored substance and a bluish-violet colored substance were dominant. Their chemical structures were not assigned because of their small quantity and instability. It was recognized that the colored substances were metabolites of SA-504 from the studies with ${ }^{3} \mathrm{H}$ and ${ }^{14} \mathrm{C}$ labelled $S A-504$ and the derivatives of SA-504.
\end{abstract}

1,1-Dimethyl-5-methoxy-3-(dithien-2-ylmethylene) piperidinium bromide (timepidium bromide, SA-504) was synthesized by Kawazu, et al." and was shown by Tamaki, et al.2) to have a potent anticholinergic activity. Studies on the absorption, distribution and excretion of SA-504 was done by Yoshikawa ${ }^{3}$, and the metabolism was studied by Meshi, et al.4) Since they observed coloration of urine and bile after oral administration of a high dose of SA-504 to rat, in the present study it was experimented in rats to find out whether these colors were due to metabolites of SA-504 or abnormal substances of biological origin.

\section{Material and Method}

\subsection{Synthesis of labeled compounds}

${ }^{14} \mathrm{C}-\mathrm{SA}-504$ was synthesized by the quaternization of tertiary nitrogen of piperidine with ${ }^{14} \mathrm{C}$-methyl bromide, as described in the previous paper). The specific activity of the product was $3.1 \mu \mathrm{Ci} / \mathrm{mg}$ and the radiochemical purity was more than $98 \%$ as determined by thin-layer chromatography (TLC).

${ }^{3} \mathrm{H}-\mathrm{SA}-504$ was prepared by the catalytic hydrogenation of brominated tertiary amine of SA-504 with tritium gas followed by quaternization with methyl bromide. The specific activity of the product was $2.3 \mu \mathrm{Ci}$ / $\mathrm{mg}$ and the radiochemical purity was more than $98 \%$.

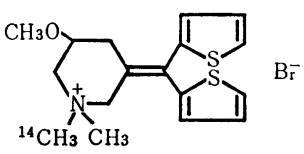

(1)

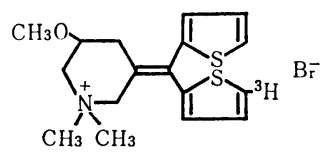

(2)
Fig. 1 Structures of ${ }^{14} \mathrm{C}-\mathrm{SA}-504$ (1) and ${ }^{3} \mathrm{H}-\mathrm{SA}-504$ (2).

1.2 Preparation of bile and urine sample

To study the relationship between radioactivity and absorption intensity of colors, a mixture of ${ }^{3} \mathrm{H}-\mathrm{SA}-504$ and ${ }^{14} \mathrm{C}-\mathrm{SA}-504$ diluted with nonradioactive SA-504, was administered orally in a dose of $500 \mathrm{mg} / \mathrm{kg}$ to 5 Wistar strain rats weighing about 300 g. The levels of ${ }^{3} \mathrm{H}$ and ${ }^{14} \mathrm{C}$ administered to a rat were $11.4 \mu \mathrm{Ci}$ and $5.6 \mu \mathrm{Ci}$, respectively.

The animals were placed in cages constructed to permit separate collection of urine and feces. Urine was collected for 24 hrs freezing immediately with a mixture of solid carbon dioxide and acetone.

Polyethylene catheter was inserted into the bile duct of rat anesthetized with ethyl carbamate and bile juice was collected for $1 \mathrm{hr}$ after intravenous administration of SA-504 or its derivatives (dose: in Table 1). Characteristics of colored substances, and 
the relationship between absorption spectrum of bile juice and chemical structure of administered compounds were examined.

\subsection{Characteristics of colored substances}

Solubility of colored substances in some organic solvents, their spectral characteristics, change of absorption spectrum with time, the effect of $\mathrm{pH}$ and of oxygen atmosphere (air) were studied for urine and bile collected after administration of a high dose of nonradioactive SA-504. Furthermore, colored substances in urine were isolated with silica gel or Sephadex G-10 column and the effect of $\mathrm{pH}$, and the qualitative analysis for sulfur and nitrogen were examined. Measurement of absorption spectrum was carried out with a Hitachi Double Beam Fluorospectrophotometer (type 356) using $10 \mathrm{~mm}^{2}$ quartz cells. The qualitative analysis for sulfur and nitrogen was carried out by fusion with metallic sodium ${ }^{5}$.

1.4 The relationship between color development and chemical structure of administered compounds

The presence of colors in bile collected from rats administered various derivatives of SA-504 intravenously, was studied and the relationship between color development and chemical structure of colored substances was discussed.

\subsection{Separation of colored substances}

The column chromatography for separation of urinary colored substances was done in the low temperature room $\left(4^{\circ}\right)$. Twenty four-hour urine from 5 rats was passed through a silica gel column $(2.5 \times 35 \mathrm{~cm})$ and washed with $500 \mathrm{~m} l$ of distilled water and eluted with $300 \mathrm{~m} l$ of $1 \%$ ammonia water. The eluate and effluent solutions were collected to $5 \mathrm{~m} l$ fractions in a fraction collector. Higher colored fractions were combined and concentrated to a small volume with a vacuum freezing dryer. Furthermore, the sample was passed through the Sephadex G-10 column $(2 \times 20 \mathrm{~cm})$ and eluted with distilled water and collected to $5 \mathrm{~m} l$ fractions in a fraction collector.

The urine collected from rats were administered nonlabelled SA-504, was used to study characteristics of the colored substances separated by the above mentioned procedures. The urine from rats administered ${ }^{14} \mathrm{C}-,{ }^{3} \mathrm{H}-\mathrm{SA}-504$, was measured of absorption intensity at $570 \mathrm{~nm}$ and radioactivity in each fraction. Fractionated solution which contained colored substances was spotted on silica gel plates (Kieselgel $\mathrm{GF}_{254}$, $0.25 \mathrm{~mm}$ thickness, activated at $110^{\circ}$ for 30 $\mathrm{min}$ ) and developed by ascending technique with the solvent I: ethanol-water-28\% ammonia water $(18: 1: 1, \mathrm{v} / \mathrm{v}), \mathrm{II}: n$-butanol -ethanol-2 $N$ ammonia water (1:1:2, v/v), III: methanol-water $(1: 1, \mathrm{v} / \mathrm{v})$. The colored bands were scraped from the plate and the radioactivity was determined by a liquid scintillation spectrometer (Aloka, LSC-502).

\section{Results}

2.1 Characteristics of colored substances

The urine or bile samples gave a reddishviolet color and its absorption maximum

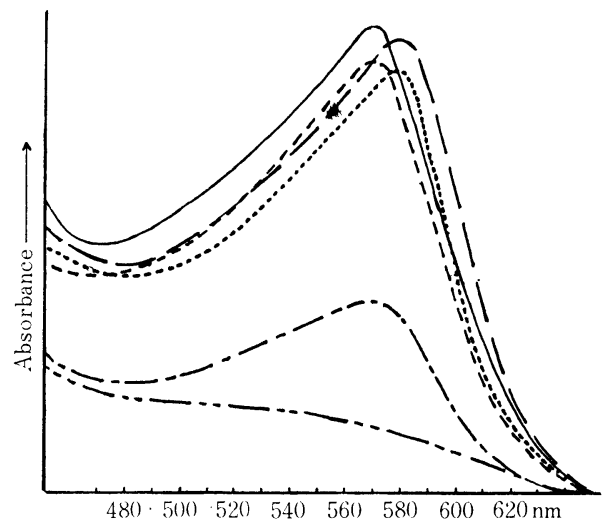

Fig. 2 Influence of various $\mathrm{pH}$ on absorption spectra of 24 hours rat-urine after oral administration.

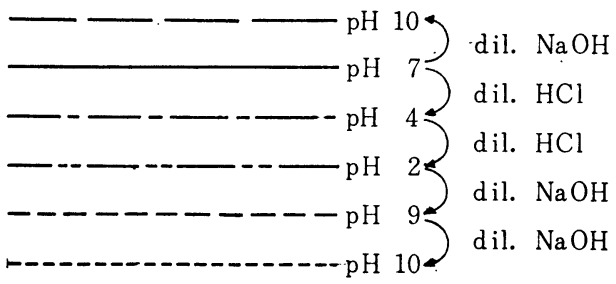


was observed at about $570 \mathrm{~nm}$. When the colored bile or urine samples were shaked with 2 volumes of organic solvents (chloroform, $n$-butanol, ethyl acetate, etc.), colored substances were not extracted with any organic solvents.

When the colored urine sample was left standing at room temperature $\left(23-25^{\circ}\right)$, the absorption maximum $\left(\lambda_{\max }: 570 \mathrm{~nm}\right)$ observed at the initial time shifted to longer wave length and the maximum color intensity decreased slowly with time. After $16 \mathrm{hrs}$ the absorption maximum disappeared and the color changed to yellowish-brown. On the other hand, when the colored urine sample was left standing at $2-4^{\circ}$, these changes were less marked on the 2 nd day. On the colored bile sample, the same influence of time and temperature was observed.

When the urine sample was acidified by $N \mathrm{HCl}$ solution, the color varied to pale yellow at $\mathrm{pH} 2$ and the absorption maximum disappeared. Then, when acidic solution

Table 1 Correlation between the structure and the formation of pigment in the bile

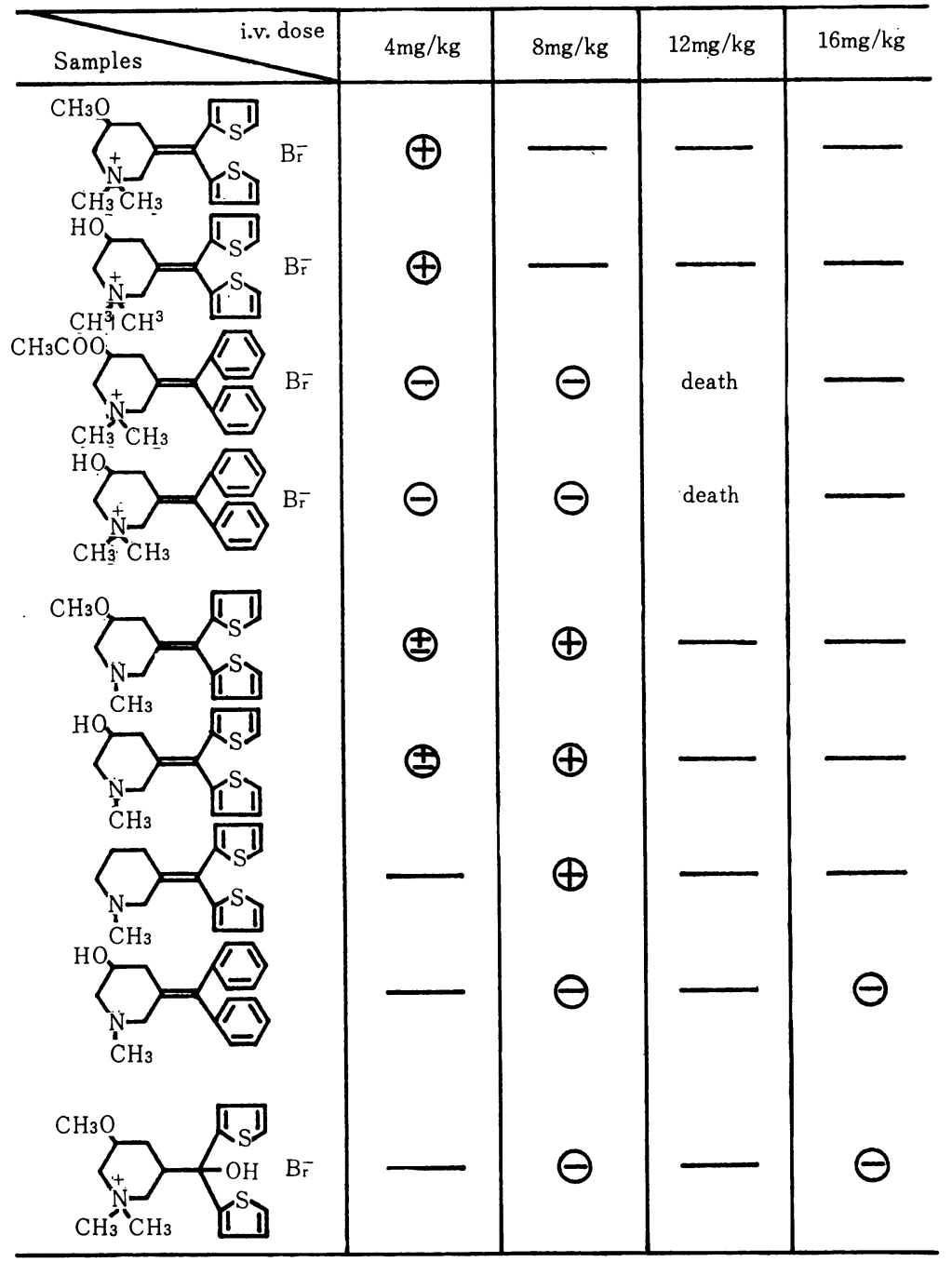

$\bigoplus$ : appearance of a reddish-violet color

$\Theta$ : no appearance of a reddish-violet color 
was alkalized by $N \mathrm{NaOH}$ solution, the urine recovered reddish-violet color and the new absorption maximum was observed at $580 \mathrm{~nm}$ (Fig. 2). On the colored bile sample, the same effect of $\mathrm{pH}$ was shown.

When the urine sample was left standing under air for $16 \mathrm{hrs}$, the color and the absorption maximum of the initial colored urine disappeared as mentioned above. However, when the sample was left standing under a nitrogen atmosphere at room temperature $\left(23-25^{\circ}\right)$, the color or the absorption spectrum did not change.

\subsection{The relationship between color deve-}

lopment and chemical structure

The reference compounds of SA-504 were administered intravenously to rats in various dosage and the coloring of excreted bile was studied. From these results, when the tertiary amine derivative of SA-504 or the derivatives varied to other substituents at 5-position of the piperidine ring were administered to rats, the colored bile juice samples were excreted. Furthermore, when the tertiary or quaternary amine compounds in which the thiophene ring of SA-504 was converted to a benzene ring, or compounds which did not have double bond at 3-position of the piperidine ring of SA-504, were administered, the excreted bile juice did not show the coloring even after lethal dose (Table 1).

\subsection{Separation of colored substances}

Separation of colored substances in urine were performed by the procedure shown in chart 1 .

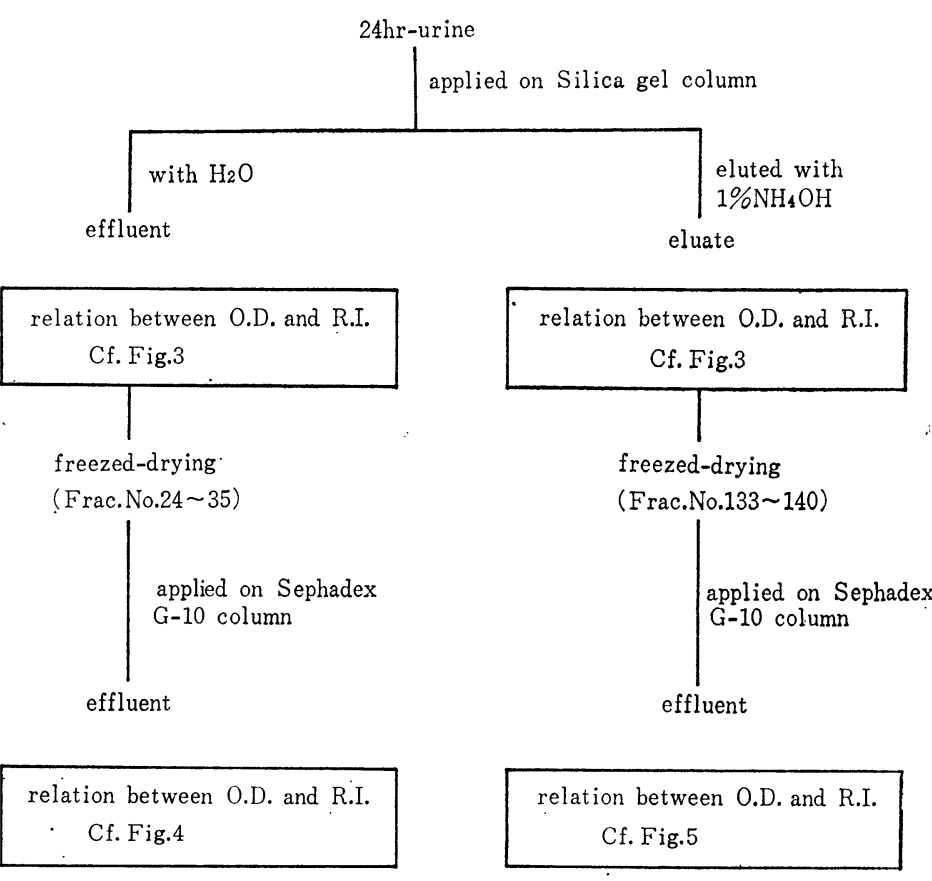

Chart. 1 Separation of urinary pigments.

The colored urine sample was applied on a silica gel column and the column was washed with distilled water and effluent was fractionated. Then, the fractionated solution which contained highly concentrated color was applied on a Sephadex G-10 column and a reddish-violet colored sub-

\section{stance was separated.}

On the other hand, a bluish-violet colored substance which stained to the top of the silica gel column was eluted with $1 \% \mathrm{NH}_{4} \mathrm{OH}$ solution and purified with a Sephadex G-10 column. The qualitative analysis showed that the both separated colored substances 
had sulfur and nitrogen.

When labelled SA-504 was administered orally to rats, two percent of the administered radioactivity was excreted in the 24 hr urine. The colored substances were separated with a silica gel column, as shown in Fig. 3. Fractions 24-35 and fractions 133140 contained high concentrations of colored substances. These fractions were applied on a Sephadex G-10 column and relatively pure colored substances were separated. On each stepwise of purification of the colors, the relationship between radioactivity and absorbance was studied. The fraction showing a more intense coloration had higher radioactivity and this relationship was recognized in each step, as shown in Figs. 3-5. The radioactivity in the reddish-violet fraction and the bluish-violet fraction separated by this separation procedure was

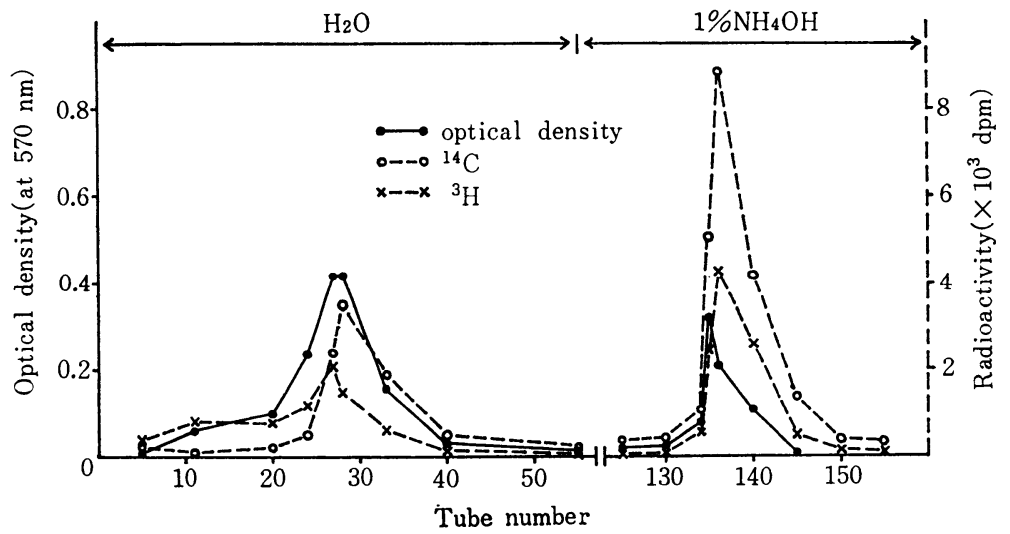

Fig. 3 The relationship between optical density and radioactivity of the pigment separated with silica gel column. sample: rat $24 \mathrm{hr}$-urine, column size: $2.5 \times 35 \mathrm{~cm}$, flow rate: $0.5 \mathrm{ml} / \mathrm{min}$, fraction volume: $5 \mathrm{ml}$

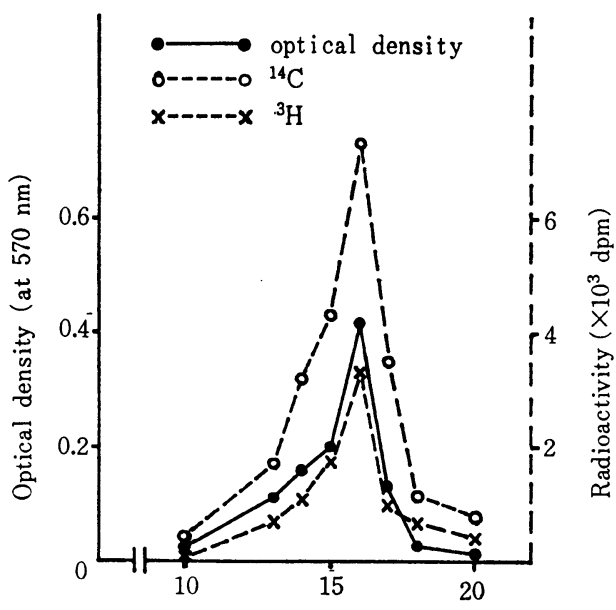

Tube number

Fig. 4 The relationship between optical density and radioactivity of the pigment separated with Sephadex G-10 column.

sample: fraction number $24 \sim 35$ (Fig. 3) column size: $2 \times 20 \mathrm{~cm}$,

flow rate: $0.5 \mathrm{ml} / \mathrm{min}$, fraction volume: $5 \mathrm{ml}$

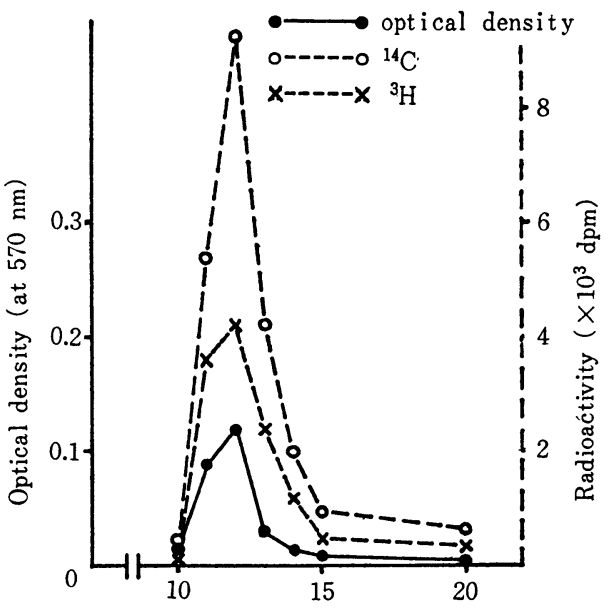

Tube number

Fig. 5 The relationship between optical density and radioactivity of the pigment separated with Sephadex G-10 column.

sample: fraction number $133 \sim 140$ (Fig. 3) column size: $2 \times 20 \mathrm{~cm}$,

flow rate: $0.5 \mathrm{ml} / \mathrm{min}$, fraction volume: $5 \mathrm{ml}$ 
about $9 \%$ and $7 \%$ of the radioactivity in urine, and were equivalent to $0.18 \%$ and $0.14 \%$ of the administered radioactivity, respectively.

Furthermore, when the purified reddishviolet colored substance was subjected to TLC with solvent systems I, II, and III in ascending technique, colored bands were detected on $\mathrm{Rf} 0.0,0.8,0.4$ respectively and these bands coincided with radioactive bands. Since the purified bluish-violet colored substance was a very small amount and a less intense coloration, the relationship between its absorption intensity and radioactivity could not be investigated by TLC.

\section{Discussion}

When SA-504 was administered orally to rats in a high dose, a coloration of bile and urine was observed. The coloring was due to metabolites of SA-504 or it might be owing an abnormal biological metabolism. Then, chemical structures of the colored substances were examined, which could not be assigned, because of so small amounts of them as $0.18 \%$ and $0.14 \%$ of dose, respectively, and because they were insoluble in organic solvents, unstable under oxygen atmosphere (air), and decolored under acidic conditions. Therefore, it did not succeed to separate purely the colored substances and assign their chemical structures.

Then, the relationship between color development in urine or bile and chemical structure of administered drugs was studied by using several reference compounds of SA-504. From these results, it was recognized that thiophene ring and double bond at the 3-position of piperidine ring were prerequisite for the coloring.

When ${ }^{3} \mathrm{H}$ - and ${ }^{14} \mathrm{C}-\mathrm{SA}-504$ mixture solution was administered to rats the relation- ship between the absorption intensity and radioactivity of ${ }^{3} \mathrm{H}$ or ${ }^{14} \mathrm{C}$ was proportional. This shows that both colors have thiophene and piperidine rings and furthermore, the carbon at the 5-position of thiophene ring and the quaternary amine of piperidine ring do not alter. From these results, it was suggested that the colored substances were metabolites of SA-504.

It is further suggested that colored urine will not be observed in humans administered a clinical dose of SA-504, because these urinary colored substances, if any, are excreted in very small quantities in rat. Even in such clinical cases where colored urine was actually observed, the degrees of coloration were low and clinical urine tests (e.q., urobilinogen test) were not affected by these substances ${ }^{6}$.

\section{Acknowledgement}

The authors wish to express their appreciation to Dr. J. Kawanishi, Department Head of this Research Laboratory, for his interest and encouragement, and to Mr. M. Yoshikawa for his cooperation in preparing the labelled SA-504. The technical assistance of Mr. T. Yagishita is gratefully recognized.

\section{References}

1) M. Kawazu, T. Kanno, S. Saito and H. Tamaki: J. Med. Chem., 15, (9) 914 (1972)

2) H. Tamaki, S. Harigaya and A. Kiyomoto: Jap. J. Pharm., 22, 685 (1972)

3) M. Yoshikawa: Pharmacometrics, in press

4) T. Meshi, S. Nakamura and T. Kanno: Chem. Pharm. Bull., 21, 1709 (1973)

5) R.L. Shriner, R.C. Fuson and D.Y. Curtin: "The systematic identification of organic compounds" Maruzen Co., Ltd. (Tokyo) 1959, p. 57

6) T. Yuasa, et al.: Personal communication. 
旨

\title{
Timepidium Bromide (SA-504) の代謝
}

\section{—ラットにおける不安定代謝物の検討——}

\author{
杉原重孝，多賀尚正* \\ 田辺製薬株式会社総合研究所, 薬物代謝研究部, $*$ 同有機化学研究部 \\ 335 埼玉県戸田市川岸2-2-50
}

\begin{abstract}
SA-504をラットに経口または静脈内投与し，尿扰よび胆汁中に排泄される呈色物質の検討を行 った。呈色物質は少なくとも2 種類以上存在した。それらはいずれも微量であり，しかも不安定で あるため，その単離打よび構造決定には至らなかった。しかし， SA-504の ${ }^{14} \mathrm{C}$ 扣よび ${ }^{3} \mathrm{H}$ 標識化 合物, 並びにその関連化合物を用いて検討した結果, 呈色物質は生体の異常代謝により生じた色素 に由来するるのではなく，SA-504自身に上る代謝物であることが推定できた。
\end{abstract}

